CR

27,3

194

Received 26 February 2016 Accepted 7 March 2016

\section{Emerging countries' country-specific advantages (CSAs) and competitiveness of emerging market multinational enterprises (EMNEs)}

\author{
Philippe Gugler
}

Faculte des Sciences Economiques et Sociales, Universite de Fribourg, Fribourg, Switzerland

\begin{abstract}
Purpose - A significant stream of literature focuses on host countries' locations when explaining why firms internalize some of their activities in specific countries. At first glance, home location schemes and specificities seem to have attracted less attention in the scientific community. The purpose of this contribution is to provide a literature review linked to the specific issue of emerging countries' country-specific advantages and the competitiveness of emerging market multinational enterprises.
\end{abstract}

Design/methodology/approach - The approach is to present the main theoretical developments related to the role of home countries in the internationalization process of domestic firms in general and as far as the home context of emerging countries is concerned.

Findings - A rigorous analysis of the literature shows that theoretical developments and empirical studies on international business do refer explicitly or at least implicitly to the role of home countries in the international expansion of firms.

Originality/value - The value of this review is to develop the main streams of the literature and to serve as a basis for the other contributions published in this area.

Keywords International business, Competitiveness, Country-specific advantages, Emerging market multinational enterprises

Paper type Literature review

\section{Introduction}

Emerging market multinational enterprises (EMNEs) have been players in the international arena for approximately three decades (Dunning et al., 2008, p. 158; Gammeltoft et al., 2010, p. 95; Parente et al., 2013, p. 453), but their competitiveness in international trade and investment has generated new momentum since the beginning of the 2000s. The globalization of markets has offered tremendous opportunities for EMNEs to invest abroad (Sinkovics et al., 2014, p. 677), and their expansion has challenged the international business (IB) community (Giulani et al., 2014, p. 680). Is the "traditional theoretical" framework in IB sufficient to explain the international expansion of EMNEs? Do EMNEs differ from developed economies' MNEs as far as their motivations, location choices, modes of entry, organizational modes and relationships with recipient countries' domestic firms and institutions? What are the roots and drivers of EMNEs' competitiveness? What will be the next steps in their international involvement abroad? Scholars have been puzzled by these questions in recent years.
Competitiveness Review Vol. 27 No. 3, 2017 pp. 194-207

(C) Emerald Publishing Limited 1059-5422

DOI $10.1108 /$ CR-02-2016-0016 
A significant stream of literature focuses on host countries' locations when explaining why firms internalize some of their activities in specific countries. At first glance, home location schemes and specificities seem to have attracted less attention in the scientific community (Rugman and Nguyen, 2014, p. 54). However, a rigorous analysis of the literature shows that theoretical developments and empirical studies on IB do refer explicitly or at least implicitly to the role of home countries in the international expansion of firms. Firms may internalize features of their home country-specific advantages (CSAs) and exploit them across national boundaries (Buckley et al., 2012, p.879). According to Rugman and Nguyen (2014, p. 53):

CSAs are exogenous location factors in a country that represent economic and institutional environments (including geographic location, factor endowments, government policies, national culture, institutional framework, and industrial clusters).

As Meyer et al. (2011, p. 239) argue, "First, firms are shaped by the home context from which they originate". "At the same time, MNEs' embeddedness in their home contexts may act as either inducements or constraints on some types of overseas business activities" (Meyer et al., 2011, p. 239).

A crucial question is to examine the theoretical ideas and/or empirical evidence on the role of home CSAs in the internationalization process and the international strategies of EMNEs and, more specifically, how CSAs can be transformed into firm-specific advantages (FSAs) in the case of EMNEs. Rugman defines an FSA "[...] as a unique capability proprietary to the organization. It may be built upon product or process technology, marketing, or distributional skills" (Rugman and Li, 2007, p. 334). As highlighted by Buckley et al., this question deserves more theoretical and empirical exploration (Buckley et al., 2012, p. 879). Specific attention has also been given to the evolving interactions between home CSAs and EMNEs' FSAs over the recent period, which has been characterized by several different "waves" of emerging countries' foreign direct investment (FDI). Are EMNEs still driven by strong CSAs, as suggested inter alia by Rugman in the 2000s or are EMNEs increasingly relying on their FSAs? EMNEs are not commonly recognized as a "homogeneous group" (Luo and Tung, 2007, p. 483; Ramamurti, 2008, p. 1). Therefore, the approaches to these questions will need to be specific while still attempting to extract some common evidence.

This contribution contains four parts. Section 2 reflects on some of the main ideas regarding the role of MNEs' home-based location in the IB literature. This section is far from an exhaustive literature review but rather examines a selection of specific topics that play an important role in the understanding of EMNEs' internationalization process. Section 3 focuses on the role of emerging countries as the home-based locations of their MNEs. According to Cantwell and Barnard (2008, p. 56), the features of the home country must be considered when scrutinizing the specific ownership advantages of emerging countries' firms. Thus, Section 3 leads to Section 4, which is dedicated to the links between the home-based context and the competitive advantages of EMNEs as far as their evolution and intensity are concerned. The evolving interactions among the CSAs of home and recipient countries as well as those between the CSAs of all locations and EMNEs' FSAs are tackled in Section 5 .

\section{The general IB framework regarding the role of the home-based location}

The locational patterns that influence the international expansion of firms are reflected in the main IB pillars that address the drivers of firms' strategies and competitiveness in international markets (Cuervo-Cazurra, 2012, p. 154; Peng et al., 2008, p. 920; Sun et al., 2012, pp. 5-6). The "industry-based view" (Porter, 1990, 2008), the "resource-based view" (Barney, 1991; Dunning and Lundan, 2008, p. 120) and the "institution-based view" (Dunning and 
$\mathrm{CR}$ 27,3

196

Lundan, 2008, p. 129; Peng et al., 2008, pp. 930-931) address the role of the home country in the propensity of MNEs to invest abroad.

According to the "investment development path", the propensity of firms to invest in foreign production depends upon the characteristics of the home country and the potential host countries (Dunning, 1981, p. 34). The choice of recipient countries and the mode of ownership are also shaped by the similarities and differences between home and host countries. Theoretical and empirical studies have focused on the "psychic distance" among home countries and host countries as reflected in the Uppsala model (Johanson and Vahlne, 1977, p. 24; Johanson and Vahlne, 2009, p. 1423). Different types of distance (e.g. geographical, cultural, institutional, technological) also reflect the specific context of the home country in comparison with other countries (Berry et al., 2010; Chang, 2011). Scholars have particularly focused on cultural and institutional distances in attempts to explain the entry mode choice of EMNEs (Chang et al., 2012; De Beule et al., 2014; Xu et al., 2011). For example, Nicholson and Salaber (2013, pp. 969-970) consider cultural distance in their analysis of Indian and Chinese MNEs' cross-border acquisitions abroad.

The location-specific advantages of the eclectic paradigm implicitly refer to the home country context (Dunning and Lundan, 2008, p. 101). According to Dunning, the home-based assets influence the owner-specific advantages (O-advantages) of firms, which have already been considered by the pioneers of studies investigating international trade and investment, such as Vernon (1966). According to Dunning and Lundan, the O-advantages in Vernon's approach are "[...] determined by the structure and pattern of their home country factor endowments, institutions and markets" (Vernon, 2008, p. 85).

Dunning acknowledges that the O-advantages correspond to Porter's views regarding firms' competitive advantages that drive the ability of firms to succeed in international markets (Dunning and Lundan, 2008, p. 109; Porter, 1990). In this regard, as stated by Porter, the international competitiveness of firms in a specific industry depends on several factors, including a favorable framework of home country conditions that constitutes the "diamond" of the business environment (Porter, 1990, pp. 69-70). The link between the internationalization of MNEs in the IB literature and the specificities of the home country diamond in Porter's framework has been recognized by eminent IB scholars such as Rugman and Verbeke (2001, p. 12) and Dunning (2009, p. 16).

The "strategic importance of the local environment" of the home country is reflected in Rugman's matrix of CSAs/FSAs (Rugman and Li, 2007, p. 335). According to Rugman, the competitive advantages of a specific firm may be scrutinized and identified according to its home CSAs and its FSAs. Four scenarios may be deduced from Rugman's matrix that depends on the strengths or weaknesses of both the CSAs and FSAs.

Most studies analyzing EMNEs activities in the 1990s and the beginning of the 2000s consider that EMNEs' competitive advantages are mostly based on strong home CSAs, whereas their FSAs are rather weak (Debrah et al., 2000, p. 319; Dunning et al., 2008, pp. 174, 177; Luo and Tung, 2007, p. 482; Nelson and Pack, 1999, pp. 432-433; Ramamurti, 2008, p. 7; Rugman, 2008, pp. 96-97 in the case of Chinese MNEs; Rugman, 2010). From this departure point, the following two sections address the home country context of EMNEs (CSAs) and EMNEs' competitive advantages (FSAs) from a dynamic perspective by analyzing the evolution of these two patterns of EMNEs' international expansion. One important question to tackle is whether the new trends in EMNEs' expansion abroad reflect changes in the origin of EMNEs' competitive advantages that involve an increasing role of FSAs compared with what has been the case in the past. The final section considers the roots of the potential dynamic interactions between the location-bound CSAs of recipient countries and home 
countries in the context of upgrading EMNEs' FSAs because of strategic asset investment abroad, among other factors.

\section{The home-base context of emerging market multinational enterprises}

The home-base context is one of the first features to consider when studying the internationalization process of EMNEs. Insofar as it challenges developed economies' MNEs, the home-base context is by definition quite different from developed economies' business and institutional conditions. As noted by Contractor (2013, p. 305):

After all, emerging market multinationals (EMMs) suffer from a double disadvantage of ordinary

"liability of foreignness" [...] and also, in addition, the liabilities of a developing country home base.

The national macroeconomic and microeconomic context shape domestic firms' FDI, as confirmed by numerous studies on EMNEs, in particular on Chinese MNEs (Tolentino, 2012, p. 73; Wei et al., 2012, pp. 47-50). Although EMNEs are not homogeneous, the same observation applies as far as emerging economies are concerned. Their levels of development from macroeconomic and microeconomic perspectives differ significantly. These different rates of development differentially affect emerging countries' domestic firms, as stated in the investment development path that reflects "the changing competitive advantages of firms" (Dunning et al., 2008, p. 164). Countries' level of development is a major factor in explaining its stage of investment abroad through its influence on firms' O-advantages (Buckley et al., 2008, p. 108; Dunning, 1981, p. 31; Dunning, 1986, pp. 671-674).

The home country context may have direct and indirect effects (positive and negative) on the willingness and ability of domestic firms to internationalize some of their activities in the value chain (Cuervo-Cazurra, 2011, pp. 383-384; Parente et al., 2013, p. 457). The studies of Fleury and Leme Fleury illustrate the "pull" and "push" effects in the case of Brazilian MNEs' policy issues, which are reflected in cultural issues for the first type of effect and regulatory reforms for the second type (Fleury and Leme Fleury, 2014, pp. 258-262). The main disadvantages of emerging countries' contexts that have been identified in the literature are institutional constraints and instability as well as domestic-market constraints (Luo and Tung, 2007, pp. 481-482, 486; Luo and Wang, 2012, p. 245; Peng and Parente, 2012, p. 361; Wu and Chen, 2014, p. 863). These weaknesses may lead firms to "escape" and internationalize some of their activities (Peng and Parente, 2012; p. 361; Witt and Lewin, 2007). Another influence of home-context disadvantages on FDI is reflected in the situation where domestic firms build specific capabilities to cope with the disadvantages, which ultimately will act as FSAs (Porter, 1990, pp. 81-86; Porter, 2008, pp. 189-190; Ramamurti, 2008, p. 7; Witt and Lewin, 2007, p. 581).

Several studies have highlighted the main CSAs that EMNEs leverage to invest and compete internationally (Buckley et al., 2008, 2012; Cantwell and Barnard, 2008; Gammeltoft et al., 2012; Ramamurti, 2008). Such CSAs may include, for example, a large domestic market and the availability of low-cost labor, as in the cases of China and India; the use of the English language in India; easy access to financial resources in China; and SOE statutes in China and Singapore (Ramamurti, 2008, p.6). Meyer et al. identify resources, endowments and institutions as the main features of the local context at home and abroad in markets where MNEs are located (Meyer et al., 2011, p. 239). Buckley et al. (2012) analyze foreign acquisitions by Indian MNEs over the period from 2000-2007. They find that some specific home country features, such as the cost of capital, the exchange rate and knowledge of English, have positive effects on foreign acquisitions by Indian firms (Buckley et al., 2012, pp. 884-887).

Home country policies regarding OFDI and, in particular, policy shifts from a restriction or even ban on OFDI to supportive incentives for investment abroad are at the core of the 
$\mathrm{CR}$ 27,3

198

evolution of EMNEs, as explained, for example, in the case of BRIC countries' MNEs (Sauvant et al., 2010, p. 17; Van Tulder, 2010, p. 64). The institutional context plays an important and different role (compared with that of developed economies) in the internationalization process of EMNEs (Dunning et al., 2008, p. 173; Gammeltoft et al., 2012, p. 177). EMNEs' FDI is shaped by:

[...] unique institutional characteristics (Yiu et al., 2007, p. 520). Wu and Chen "argue that [a] better-developed home country institutional environment promotes emerging market firms' expansion to foreign markets more advanced than the home country (Wu and Chen, 2014, p. 862).

Buckley et al. (2008) refer to the "institution-based view of firm strategy" to emphasize the important role of the home country's constraints and opportunities in the internationalization of domestic firms (Buckley et al., 2008, p. 109). According to Wu and Chen (2014, p. 862):

[...] an institutional-based approach can offer an insightful analysis of the impact of [the] institutional environment of emerging markets on indigenous firms' propensity [for] foreign expansion.

As noted by Ren et al., not only formal institutions but also informal institutions influence Chinese FDI (Ren et al., 2012, p. 24).

Governmental support of investments abroad constitutes a specific characteristic of emerging countries that has been highlighted by many studies (Luo and Tung, 2007, pp. 482, 486; Luo et al., 2010, p. 68; Peng and Parente, 2012, p. 360; Wu and Chen, 2014, p. 864). Such support is particularly important for Chinese MNEs and specifically SOEs (Luo et al., 2010, p. 68; Wu and Ding, 2009, pp. 174-175). However, most emerging countries other than China also register important SOEs whose role in international markets may still generate new momentum (Gammeltoft et al., 2012, pp. 177-178).

We may consider that CSAs - as developed by Rugman - are mostly "inherited assets". In contrast, FSAs are "created assets" that result from the specific firm's efficiency, strategy and operations (Porter, 2008, p. 38). As inherited assets, are CSAs public goods? In other words, are CSAs open to any domestic firm in a specific country? According to some scholars, the answer is affirmative (Lessard and Lucea, 2009, p. 282). They argue that internationalization strategies based only on home country CSAs are not sustainable because these advantages are common to all domestic firms and, therefore, do not confer unique advantages to specific firms (Lessard and Lucea, 2009, p. 283). However, others argue that CSAs are not common to all companies competing in a specific country because the features of the CSAs have different effects according to the types of firms, industries, markets, etc. (Porter, 1990, p. 71, 2008, p. 182). As stated by Hennart, "[...] most CSAs are not freely available to foreign investors" (Hennart, 2012, p. 168). Some CSAs are specific to particular types of firms, such as SOEs. Furthermore, SOEs compete in a limited number of industries. According to Ramamurti, CSAs are at least "imperfect public goods" (Ramamurti, 2008, p.8, 2009, pp. 411-412). Narula calls them "quasi public goods" (Ramamurti, 2012, p. 190). Therefore, it would be inaccurate to consider CSAs a "one size fits all" feature for all domestic firms competing in a specific country. CSAs are industry specific and even firm specific because they cannot be dissociated from the firms' competitiveness (FSAs).

\section{The home-base context and emerging market multinational enterprises' competitiveness}

As stated above, many studies consider - or have considered - that EMNEs' foreign investments are mostly based on O-advantages resulting from CSAs rather than from FSAs. As far as Chinese MNEs are concerned, the main weaknesses of the FSAs that have been 
identified are poor technological know-how, management skills and value-chain integration (Ren et al., 2012, p. 11; Rugman and Li, 2007, p. 326). These findings reflect the main results of the IB literature, which states that $\mathrm{O}$-advantages are influenced by the location advantages of the home country, at least during the first phase of internationalization (Narula and Nguyen, 2011, p. 3; Vernon, 1966, p. 193). According to Ramamurti, EMNEs have relied more on CSAs because they were "early stage" MNEs compared with developed markets' "mature" MNEs (Ramamurti, 2004, p. 280, 2013, p. 6). However, EMNEs are no longer in an initial phase of internationalization; it is recognized that EMNEs have developed over the course of different waves of internationalization processes (Mathews, 2006, p. 8; Di Minin et al., 2012, p. 191). Since the 1990s, we have observed important shifts regarding the primary motives, leading strategies, ownership modes, industrial distribution, types of activities in the value chain and destinations of EMNEs (Gammeltoft, 2008, p. 3). The nature of their O-advantages may have also evolved over time (Lessard and Lucea, 2009, pp. 290-301; Ramamurti, 2012, p. 43). This evolution in part reflects the development of EMNEs' O-advantages in intensity and also in the assets that constitute the competitive advantages. Some EMNEs expand abroad thanks to a "mixture" of CSAs and FSAs, with the latter gaining an increased role in the internationalization process (He and Fallon, 2013; Parente et al., 2013, p. 458; Ramamurti, 2009, p. 239; Williamson and Raman, 2009, p. 260). There is not only an interaction between domestic firms' FSAs and their home locations' CSAs but also a dynamic interdependence between them, with each creating positive or negative externalities for the others (Narula, 2012, p.189; Porter, 2008, p. 171). Numerous examples are given inter alia by Ramamurti (2013, p. 246) as well as Celly et al., (2013, p. 59) in the case of Indian MNEs; Williamson and Raman in the case of Chinese MNEs (Williamson and Raman, 2013, pp. 262-263); Filippov and Settles in the case of Russian EMNEs (Filippov and Settles, 2013, pp. 37-43) and De Miranda Oliveira Junior et al. (2013, p. 11) in the case of Brazilian firms.

As stated above, one of the progressive developments of the FSA component of O-advantages is reflected in the evolution of EMNEs' motivations to invest abroad. According to Dunning, the first stage of EMNEs was primarily focused on the exploitation of O-advantages, whereas the next stage also reflected "asset-augmenting" investments (Dunning, 2006, p. 139). EMNEs' FDI constitutes a "springboard" by which to acquire strategic assets abroad (Gugler and Vanoli, 2015; Holtbrügge and Kreppel, 2012; Luo and Tung, 2007, p. 482; Zhang and Roelfsema, 2014). This strategic-asset-seeking investment wave toward developed economies in particular is driven by an evolution of home-based technology capabilities, as shown in several studies on Chinese MNEs (Amighini et al., 2014; Cui and Jiang, 2009; Cui and Jiang, 2010; De Beule et al., 2014; Deng, 2009; Di Minin et al., 2012; Rui and Yip, 2008; Sun et al., 2012; Wu and Ding, 2009; Zhang and Filippov, 2009). As stated by Gammeltoft (2008, p. 3):

Many TNCs from emerging and developing economies (ETNCs) have gradually accumulated technological capabilities and firm-specific advantages sufficient to expand their operations to other countries, and flows of outward investment from emerging and developing economies have consequently increased significantly in quantitative terms.

However, the innovation capabilities of EMNEs should not be overestimated and generalized to all EMNEs at this stage. A study of four Chinese MNEs presented by He and Fallon (2013) argues that the four firms do benefit from "brilliant innovation capabilities". However, a study on the innovation capabilities of Chinese firms based on the patents registered by Chinese affiliates located in Europe shows that Chinese firms innovate, but most of their patented innovations are still based on a high percentage of foreign knowledge (Gugler and Vanoli, 2015). However, the increasing number of EMNEs' strategic-asset-seeking 
$\mathrm{CR}$ 27,3

200

investments tends to confirm the trends toward a strengthening of their FSAs. Some scholars argue that the increase in asset-augmenting investments may be related to the absence of O-advantages (Mathews, 2006, p. 17). However, as stated inter alia by Dunning, firms engaged in asset-seeking investments already possess some O-advantages (Dunning, 2006, p. 139). According to Narula and Nguyen, "the concept of asset augmentation implies that firms have existing assets which they wish to augment" (Narula and Nguyen, 2011, p. 13). One may argue that it is the FSA component of O-advantages - compared with the CSA component - that plays the most important role in the majority of strategic-asset-seeking investments.

The evolution of EMNEs' FSAs is shaped by the evolution of the home country's business environment. The nature of the CSA components in EMNEs' O-advantages has changed over time because of the increased integration of emerging countries in the world market and the inherent changes related to their institutional, structural and regulatory patterns. The home country offers not only inherited assets (CSAs) but also a productive business environment, allowing firms to innovate, be more productive, create unique value for customers and, finally, to face international competition successfully. The more sophisticated the home business environment is, the more opportunities there are for firms to developed exclusive and unique competitive assets (FSAs). For example, several studies provide empirical evidences in the case of Brazilian MNEs (de Miranda Oliveira Junior et al., 2013, p. 11; Parente et al., 2013, p. 458). According to Porter, firms develop competitive advantages based on their unique locational comparative advantages (Porter, 2008, pp. 177-178). As emphasized by Lessard, EMNEs' home countries offer a "less-than-complete 'home-based diamond" (Lessard, 2014, p. 114). However, several studies have observed an upgrading of the home diamond, thus offering new opportunities to domestic firms to strengthen their competitiveness. For example, Brandl and Mudambi describe how Indian firms caught up in four industries (auto components, pharmaceuticals, entertainment, wind turbines) because they benefitted from an upgrade of their home diamond (Brandl and Mudambi, 2014, pp. 135-145). Some recent studies on emerging countries' business environment reflect the improvement and upgrading of their microeconomic features, thus improving their domestic firms' competitiveness. In this context, the evolution of the home technological advantage also influences EMNEs' internationalization process (Yiu et al., pp. 520-526, 537; Zhang et al., 2015, p. 228).

The role of the home country may evolve over time, depending on the stage of the investment development path. As stated by Narula, "[...] the initial FSAs of an MNE tend to be constrained by the location-specific (L) assets of the home country" (Narula, 2012, p. 188). From this perspective, we may assume that the impact of the home country is primarily based on inherited assets. Then, the next stages of firms' internationalization rely on FSAs that are based on created assets within the firm but whose process of creation is also shaped by the home country's business context as well as by host countries' business environments.

\section{Interactions among home country-specific advantages, recipient countries' country-specific advantages and emerging market multinational enterprises' firm-specific advantages}

Currently, the new trend in EMNEs' international expansion tends to reflect more sophisticated FSAs built on the configuration, organization and management of their internal and external networks, with counterparts located in their portfolio of recipient countries (Mudambi, 2008). EMNEs configure their global value chain according to the advantages and disadvantages they are facing in their home and recipient countries as well as according to their own competitive advantages and disadvantages (Cuervo-Cazurra, 2013, 
p. 176). Strategic-asset-seeking investments are increasingly shaping EMNEs' investments abroad (Cui et al., 2013). As noted by Porter, "the initial location-based advantages are extended and supplemented through a global network" (Porter, 2008, p. 315). In that respect, even though EMNEs' internationalization processes differ from those of developed economies' MNEs (Luo and Wang, 2012, p. 244), the new trends involving dynamic interactions within the EMNEs' location portfolios is comparable to what has been observed in the case of developed countries' MNEs (Gugler et al., 2015; Gugler and Vanoli, 2015; Tinguely, 2013). Of course, compared with developed economies' MNEs, the current situation for EMNEs is still embryonic. Nevertheless, we may assume that it will evolve with the increasing shifts toward EMNEs developing strategic-asset-seeking investments. As mentioned above, strategic-asset-seeking investments reflect the new wave of EMNEs' expansion abroad, in particular for Chinese firms (Wu and Ding, 2009, p. 174).

FSAs are therefore influenced by numerous CSAs involving the home country and the host countries (Mudambi, 2008, p. 700; Hennart, 2012, p. 171). Thus, FSAs are a function of home country CSAs as well as of all host countries' CSAs considered as a system (Rugman and Verbeke, 2001; Gugler et al., 2015). Chaiprasit and Swierczek (2011) provide an example regarding Thai Firms in this respect. All home-host county linkages play a role (Buckley et al., 2012; Verbeke, 2009, p. 187). Multiple "diamonds" are at work that offer specific opportunities for MNEs to develop unique, competitive assets. According to Lessard, EMNEs create "a virtual diamond" by adding assets from "various host countries" (Lessard, 2014, p. 116). Firms accumulate knowledge and experience from operating in different foreign locations (Estrin and Meyer, 2013, p. 4). In this context, studies on the location choices of EMNEs (De Beule and Duanmu, 2012; Deng and Yang, 2015; Estrin and Meyer, 2013) are very important to detect the role of home country CSAs in their internationalization processes. FSAs are created because of firms' ability to develop assets that result from the unique interactions between location-bound CSAs and non-location-bound CSAs within a so-called "corporate system of innovation" (Tinguely, 2013, p. 97). A recent study on patents registered at the European Patent Office by Chinese firms located in Europe shows that 40 per cent of these patents are based on previous patents owned by domestic firms in the recipient countries (Gugler and Vanoli, 2015). However, as indicated by Rugman and Nguyen (2014, pp. 57-58), most EMNEs are still far from benefitting from the model of dynamic and efficient management of internal and external networks observed within developed economies' MNEs because they lack organizational capabilities, particularly in their subsidiaries. However, we should not neglect the networking capabilities of some EMNEs (Contractor, 2013, p. 313), in particular of Chinese firms, who may take advantage of these types of FSAs to establish global networks by tapping into the location-bound CSAs of recipient countries thanks to their location-bound and non-location bound home CSAs (Tao et al., 2013, pp. 116-118). As highlighted by Pananond (2013) in her study of the global value chain of Thai firms, it is important to consider the spillovers of overseas activities on home-based firms and home-based economies. In that respect, the dynamic interactions between host country CSAs and home country CSAs, as well as between their interactions with EMNEs' FSAs, create permanent developments in the home-base context through a permanent system of communication.

\subsection{Conclusion and proposals for further development}

The international expansion of EMNEs is a fascinating but challenging issue. Among the numerous questions raised by the involvement of EMNEs in international competition is the evolving role of the home market. The main goals of this contribution are to examine some of the theoretical ideas and empirical evidence to allow us to deepen our understanding of the 
role of emerging home countries in the internationalization process of their domestic firms and more specifically in their ability to compete successfully abroad. How much do home CSAs still influence EMNEs' OFDI? Which home country assets provide the main competitive drivers to invest and compete abroad? How do EMNEs combine home country assets and host country assets to strengthen their competitive advantages? These questions

\section{References}

Amighini, A., Cozza, C., Rabelloti, R. and Sanfilippo, M. (2014), "An analysis of Chinese outward FDIs in Europe with firm-level data”, Working Paper 2014/02, CIRCLE University of Lund.

Barney, J. (1991), "Firm resource and sustained competitive advantage", Journal of Management, Vol. 17 No. 1, pp. 99-120.

Berry, H., Guillen, M.F. and Zhou, N. (2010), "An institutional approach to cross-national distance", Journal of International Business Studies, Vol. 41 No. 9, pp. 1460-1480.

Brandl, K. and Mudambi, R. (2014), "EMNCs and catch-up processes: the case of four Indian industries", in Cuervo-Cazurra, A. and Ramamurti, R. (Eds), Understanding Multinationals from Emerging Markets, Cambridge University Press, Cambridge, pp. 129-152.

Buckley, P.J., Clegg, J.L., Cross, A.R., Voss, H., Rhodes, M. and Zheng, P. (2008), “Explaining China's outward FDI: an institutional perspective", in Sauvant, K.P. (Ed,), The Rise of Transnational Corporations from Emerging Markets: Threats or Opportunity?, Edward Elgar, pp. 107-158.

Buckley, P.J., Forsans, N. and Munjal, S. (2012), "Host-home country linkages and host-home country specific advantages as determinants of foreign acquisitions by Indian firms", International Business Review, Vol. 21, pp. 878-890.

Cantwell, J. and Barnard, H. (2008), "Do firms from emerging markets have to invest abroad? Outward FDI and the competitiveness of firms", in Sauvant, K.P. (Ed), The Rise of Transnational Corporations from Emerging Markets: Threats or Opportunity?, Edward Elgar, pp. 55-85.

Celly, N., Prabbu, J. and Subramanian, V. (2013), “Innovation by Indian EMNEs”, in Williamson, P.J., Ramamurti, R., Fleury, A. and Leme Fleury, M.T. (Eds), The Competitive Advantage of Emerging Market Multinationals, Cambridge University Press, Cambridge, pp. 46-63.

Chaiprasit, S. and Swierczek, F.W. (2011), "Competitiveness, globalization and technology development in Thai firms”, Competitiveness Review, Vol. 21 No. 2, pp. 188-204.

Chang, J. (2011), "The early and rapid internationalization of Asian emerging MNEs", Competitiveness Review, Vol. 21 No. 2, pp. 171-187.

Chang, Y.-C., Kao, M.-S., Kuo, A. and Chiu, C.-F. (2012), "How cultural distance influences entry mode choice: the contingent role of host country's governance quality”, Journal of Business Research, Vol. 65 No. 8, pp. 1160-1170.

Contractor, F.J. (2013), "Punching above their weight: the sourcing of competitive advantage for emerging market multinationals", International Journal of Emerging Markets, Vol. 8 No. 4, pp. 304-328.

Cuervo-Cazurra, A. (2011), "Global strategy and global business environment: the direct and indirect influences of the home country on a firm's global strategy", Global Strategy Journal, Vol. 1, pp. 382-386.

Cuervo-Cazurra, A. (2012), "Extending theory by analysing developing country multinational companies: solving the goldilocks debate", Global Strategy Journal, Vol. 2, pp. 153-167.

Cuervo-Cazurra, A. (2013), "How emerging market multinational enterprises upgrade capabilities using value-chain configuration in advanced economies, in Williamson, P.J., Ramamurti, R., Fleury, A. and Leme Fleury, M.T. (Eds), The Competitive Advantage of Emerging Market Multinationals, Cambridge University Press, Cambridge, pp. 174-179. 
Cui, L. and Jiang, F. (2009), "FDI entry mode choice of Chinese firms: a strategic behavior perspective", Journal of World Business, Vol. 44, pp. 434-444.

Cui, L. and Jiang, F. (2010), "Behind ownership decision of Chinese outward FDI: resources and institutions", Asia Pacific Journal of Management, Vol. 27, pp. 751-774.

Cui, L., Meyer, K.E. and Wei Hu, H. (2013), "What drives firms' intent to seek strategic assets by foreign direct investment? A study of emerging economy firms", Journal of World Business, pp. 488-501.

De Beule, F. and Duanmu, J-L. (2012), "Locational determinants of internationalization: a firm-level analysis of Chinese and Indian acquisitions", European Management Journal, Vol. 30, pp. 264-277.

De Beule, F., Elia, S. and Piscitello, L. (2014), "Entry and access to competencies abroad: emerging Market firms versus advanced market firms", Journal of International Management, Vol. 20, pp. 137-152.

De Miranda Oliveira Junior, M., Mendes Borini, F. and Fleury, A. (2013), "Innovation by Brazilian EMNEs", in Williamson, P.J., Ramamurti, R., Fleury, A. and Leme Fleury, M.T. (Eds), The Competitive Advantage of Emerging Market Multinationals, Cambridge University Press, Cambridge, pp. 11-28.

Debrah, Y.A., McGovern, I. and Budhwar, P. (2000), “Complementarity or competition: the development of human resources in a South-East Asian growth triangle: Indonesia, Malaysia and Singapore", International Journal of Human Resource Management, Vol. 11 No. 2, pp. 314-335.

Deng, P. (2009), "Why do Chinese firms tend to acquire strategic assets in international expansion?", Journal of World Business, Vol. 44, pp. 74-84.

Deng, P. and Yang, M. (2015), "Cross-border mergers and acquisitions by emerging market firms: a comparative investigation”, International Business Review, Vol. 24, pp. 157-172.

Di Minin, A., Zhang, J. and Gammeltoft, P. (2012), "Chinese foreign direct investment in R\&D in Europe: a new model of R\&D internationalization?”, European Management Journal, Vol. 30, pp. 189-203.

Dunning, J.H. (1981), "Explaining the international direct investment position of countries: towards a dynamic of developmental approach”, Weltwirtschaftliches Archiv, Vol. 117 No. 1, pp. 30-64.

Dunning, J.H. (1986), "The investment development cycle revisited", Weltwirtschaftliches Archiv, Vol. 122 No. 4, pp. 667-676.

Dunning, J.H. (2006), “Comment on dragon multinationals: new players in 21st century globalisation”, Asia Pacific Journal of Management, Vol. 23, pp. 139-141.

Dunning, J.H. (2009), "Location and the Multinational enterprise: a neglected factor?", Journal of International Business Studies, Vol. 40, pp. 5-19.

Dunning, J.H. and Lundan, S. (2008), Multinational Enterprises and the Global Economy, Edward Elgar.

Dunning, J.H., Kim, C. and Park, D. (2008), “Old wine in new bottles: a comparison of emerging-market TNCs today and developed-country TNCs thirty years ago", in Sauvant K.P. (Ed.), The Rise of Transnational Corporations from Emerging Markets: Threats or Opportunity?, Edward Elgar, pp. 158-180.

Estrin, S. and Meyer, K. (2013), "How different are emerging economy mnes? A comparative study of location choice", available at: http://personal.lse.ac.uk/estrin/Publication $\% 20 \mathrm{PDF}$ 's/How $\% 20$ Different\%20are\%20Emerging\%20Economy\%20MNEs_20130122km.pdf

Filippov, S. and Settles, A. (2013), "Innovation by Russian MNEs", in Williamson, P.J., Ramamurti, R., Fleury, A. and Leme Fleury, M.T. (Eds), The Competitive Advantage of Emerging Market Multinationals, Cambridge University Press, Cambridge, pp. 29-45.

Fleury, A. and Leme Fleury, M.T. (2014), "Country of origin effects on internationalization: insights from Brazil", in Cuervo-Cazurra, A. and Ramamurti, R. (Eds), Understanding Multinationals from Emerging Markets, Cambridge University Press, Cambridge, pp. 242-267.

Gammeltoft, P. (2008), "Emerging multinationals outward FDI from the BRICS countries", paper presented in the IV Globelics Conference, Mexico City, September. 
$\mathrm{CR}$ 27,3

Gammeltoft, P., Barnard, H. and Madhok, A. (2010), "Emerging multinationals, emerging theory: macroand micro-level perspectives", Journal of International Management, Vol. 16 No. 2, pp. 95-101.

Gammeltoft, P., Filatotchev, I. and Hobdari, B. (2012), "Emerging multinational companies and strategic fit: a contingency framework and future research agenda", European Management Journal, Vol. 30, pp. 175-188.

Giulani, E., Gorgoni, A., Günther, C. and Rabellotti, R. (2014), "Emerging versus advanced country MNEs investing in Europe: a typology of subsidiary global-local connections", International Business Review, Vol. 23, pp. 680-691.

Gugler, Ph., Keller, M. and Tinguely, X. (2015), "The role of clusters in the global innovation strategy of MNEs: theoretical foundations and evidence from the basel pharmaceutical cluster", Competitiveness Review, No. 3.

Gugler, Ph. and Vanoli, L. (2015), "Technology-sourcing investment abroad as an enhancer of Chinese MNEs' innovative capabilities”, International Journal of Emerging Markets, Vol. 10 No. 3.

He, S. and Fallon, G.R. (2013), “Chinese multinational enterprises' firm-specific advantages and a critic on the international business theory", paper presented to 40th Academy of International Business, UK \& Ireland Chapter (AIB. UK) Conference, Aston Business School, Birmingham, March.

Hennart, J.F. (2012), "Emerging market multinationals and the theory of the multinational enterprise", Global Strategy Journal, Vol. 2, pp. 168-187.

Holtbrügge, D. and Kreppel, H. (2012), "Determinants of outward foreign direct investment from BRIC countries: an explorative study", International Journal of Emerging Markets, Vol. 7 No. 1, pp. 4-30.

Johanson, J. and Vahlne, J.-E. (1977), "The internationalization process of the firm - a model of knowledge development and increasing foreign market commitments", Journal of International Business Studies, Vol. 8 No. 1, pp. 23-32.

Johanson, J. and Vahlne, J.E. (2009), "The Uppsala internationalization process model revisited: from liability of foreignness to liability of outsidership", Journal of International Business Studies, Vol. 40, pp. 1411-1431.

Lessard, D. (2014), "The evolution of EMNCs and EMNC thinking: a capabilities perspective", in Cuervo-Cazurra, A. and Ramamurti, R. (Eds), Understanding Multinationals from Emerging Markets, Cambridge University Press, Cambridge, pp. 108-128.

Lessard, D. and Lucea, R. (2009), "Mexican multinationals: insights from CEMEX", in Ramamurti, R. and Singh, J.V. (Eds), Emerging Multinationals From Emerging Markets, Cambridge University Press, Cambridge, pp. 280-311.

Luo, Y. and Tung, R.L. (2007), "International expansion of emerging market enterprises: a springboard perspective", Journal of International Business Studies, Vol. 38, pp. 481-498.

Luo, Y. and Wang, S.L. (2012), "Foreign direct investment strategies by developing country multinationals: a diagnostic model for home country effects", Global Strategy Journal, Vol. 2, pp. 244-261.

Luo, Y., Xue, Q. and Han, B. (2010), "How emerging market governments promote outward FDI: experience from China”, Journal of World Business, Vol. 45, pp. 68-79.

Mathews, J.A. (2006), "Dragon multinationals: new players in 21st century globalization”, Asia Pacific Journal of Management, Vol. 23, pp. 5-27.

Meyer, K.E., Mudambi, R. and Narula, R. (2011), "Multinational enterprises and local contexts: the opportunities and challenges of multiple embeddedness", Journal of Management Studies, Vol. 48 No. 2, pp. 235-252.

Mudambi, R. (2008), “Location, control, and innovation in knowledge-intensive industries”, Journal of Economic Geography, Vol. 8 No. 5, pp. 699-725. 
Narula, R. (2012), "Do we need different frameworks to explain infant MNEs from developing countries?”, Global Strategy Journal, Vol. 2, pp. 188-204.

Narula, R. and Nguyen, Q.T.K. (2011), "Emerging country MNEs and the role of home countries: separating fact from irrational expectations", working paper series 021, UNU-Merit.

Countryspecific advantages

Nelson, R.R. and Pack, H. (1999), "The Asian miracle of modern growth theory”, The Economic Journal, Vol. 109, pp. 416-436.

Nicholson, R.R. and Salaber, J. (2013), "The motives and performance of cross-border acquirers from emerging economies: comparison between Chinese and Indian firms", International Business Review, Vol. 22 No. 6, pp. 963-980.

Pananond, P. (2013), "Moving along the value chain: emerging thai multinationals in globally integrated industries", Asian Business \& Management, Vol. 12 No. 1, pp. 85-114.

Parente, R.C., Bruno Cyrino, A., Spohr, N. and Carvalho de Vasconcelos, F. (2013), "Lessons learned from Brazilian multinationals' internationalization strategies", Business Horizon, Vol. 56, pp. 453-463.

Peng, M.W. and Parente, R.C. (2012), "Institution-based weaknesses behind emerging multinationals", RAE, Sao Paulo, Vol. 52 No. 3, pp. 360-364.

Peng, M.W., Wang, D.Y.L. and Jiang, Y. (2008), "An institution-based view of international business strategy: a focus on emerging economies”, Journal of International Business Studies, Vol. 39, pp. 920-936.

Porter, M.E. (1990), The Competitive Advantage of Nations, Free Press.

Porter, M.E. (2008), On Competition, Harvard Business Review Book.

Ramamurti, R. (2004), "Developing countries and MNEs: extending and enriching the research agenda", Journal of International Business Studies, Vol. 35, pp. 277-281.

Ramamurti, R. (2008), "What have we learned about Emerging-market MNEs?", paper presented at the Conference on "Emerging Multinationals: Outward FDI from Emerging and Developing Economies”, Copenhagen Business School, Copenhagen.

Ramamurti, R. (2009), "Cross-border M\&A and Competitive advantage of Indian EMNEs", in Williamson, P.J., Ramamurti, R., Fleury, A. and Leme Fleury, M.T. (Eds), The Competitive Advantage of Emerging Market Multinationals, Cambridge University Press, Cambridge, pp. 239-277.

Ramamurti, R. (2012), "What is really different about Emerging Market Multinationals", Global Strategy Journal, Vol. 2, pp. 41-47.

Ramamurti, R. (2013), "The Economic Impact of Emerging Multinationals", paper presented at the "Impact of Emerging Multinationals on Global Development Conference, Politecnico di Milano, Milan, 30 May.

Ramamurti, R. (2013), "Cross-border M\&A and competitive advantage of Chinese EMNEs, in Williamson, P. J., Ramamurti, R., Fleury, A. and Leme Fleury, M.T. (Eds), The Competitive Advantage of Emerging Market Multinationals, Cambridge University Press, Cambridge, pp. 260-277.

Ren, B., Liang, H. and Zheng, Y. (2012), "An Institutional Perspective and the Role of the State for Chinese OFDI", in Alon, I., Fetscherin, M. and Gugler, P.H. (Eds), Chinese International Investments, Palgrave Macmillan, pp. 11-37.

Rugman, A.M. (2008), “How global are TNCs from emerging countries?”, in Sauvant, K.P.(Ed.), The Rise of Transnational Corporations from Emerging Markets: Threats or Opportunity?, Edward Elgar, pp. 86-106.

Rugman, A.M. (2010), "Reconciling internationalization theory and the eclectic paradigm", The Multinational Business Review, Vol. 18 No. 2, pp. 1-12.

Rugman, A.M. and Li, J. (2007), “Will China's multinationals succeed globally or regionally?”, European Management Journal, Vol. 25 No. 5, pp. 333-343. 
$\mathrm{CR}$ 27,3

Rugman, A.M. and Nguyen, Q.T.K. (2014), "Modern international business theory and emerging market multinational companies", in Cuervo-Cazurra, A. and Ramamurti, R. (Eds), Understanding Multinationals from Emerging Markets, Cambridge University Press, Cambridge, pp. 53-80.

Rugman, A.M. and Verbeke, A. (2001), "Subsidiary-specific advantages in multinational enterprises", Strategic Management Journal, Vol. 22, pp. 237-250.

Rui, H. and Yip, G.S. (2008), "Foreign acquisition by Chinese firms: a strategic intent perspective", Journal of World Business, Vol. 43, pp. 213-226.

Sauvant, K.P., Maschek, W.A. and McAllister, G. (2010), "Foreign investment by emerging market multinational enterprises, the impact of the financial crisis and recession, and challenges ahead", in Sauvant, K.P., Mc Allister, G. and Maschek, W. (Eds), Foreign Direct Investments from Emerging Markets, Palgrave Macmillan, pp. 4-34.

Sinkovics, R.R., Nadvi, K. and Zhang, Y.Z. (2014), "Editorial: rising powers from emerging markets - the changing face of international business", International Business Review, Vol. 23, pp. 675-679.

Sun, S.L., Peng, M.W., Ren, B. and Yan, D. (2012), “A comparative ownership advantage framework for cross-border M\&As: the rise of Chinese and Indian MNEs", Journal of World Business, Vol. 47, pp. 4-16.

Tao, B., Zhanming, J., Xiaoguang, Q. (2013), “Chinese firms' outward FDI entry mode choice: the role of ownership and network", Journal of Innovation Management, Vol. 1 No. 1, pp. 108-124.

Tinguely, X. (2013), The New Geography of Innovation: Clusters, Competitiveness and Theory, Palgrave Macmillan, Houndmills.

Tolentino, P.E. (2012), "The role of country of origin and Chinese OFDI", in Alon, I., Fetscherin, M., Gugler, Ph. (Eds), Chinese International Investments, Palgrave Macmillan, pp. 54-80.

Van Tulder, R. (2010), "Toward a renewed stages theory for BRIC multinational enterprises? A home country bargaining approach", in Sauvant, K.P., McAllister, G. and Maschek, W. (Eds), Foreign Direct Investments from Emerging Markets, Palgrave Macmillan, pp. 61-74.

Verbeke, A. (2009), International Business Strategy, Cambridge University Press, Cambridge.

Vernon, R. (1966), "International investment and international trade in the product cycle", Quarterly Journal of Economics, Vol. 80 No. 2, pp. 190-207.

Wei, W., Alon, I. and Ni, L. (2012), "Home country macroeconomic determinants of Chinese OFDI", in Alon, I., Fetscherin, M. and Gugler, P.H. (Eds), Chinese International Investments, Palgrave Macmillan, pp. 38-53.

Williamson, P.J. and Raman, A.P. (2009), "Cross-border M\&A and Competitive advantage of Chinese EMNEs", in Williamson, P.J., Ramamurti, R., Fleury, A. and Leme Fleury, M.T. (Eds), The Competitive Advantage of Emerging Market Multinationals, Cambridge University Press, Cambridge, pp. 260-277.

Witt, M.A. and Lewin, A.Y. (2007), "Outward foreign investment as escape response to home country institutional constraints", Journal of International Business Studies, Vol. 38, pp. 579-594.

$\mathrm{Wu}, \mathrm{J}$. and Chen, X. (2014), "Home country institutional environments and foreign expansion of emerging market firms", International Business Review, Vol. 23, pp. 862-872.

Wu, X. and Ding, W. (2009), "Chinese firms' internationalization paths by strategic asset-seeking outward foreign direct investment”, PICMET 2009 Proceedings, Portland, OR, 2-6 August, pp. 173-179.

Xu, Y., Hu, S. and Fan, X. (2011), "Entry mode choice of Chinese enterprises: the impacts of country risk, cultural distance and their interactions", Frontiers of Business Research in China, Vol. 5 No. 1, pp. 63-78.

Yiu, D.W., Lau, C. and Bruton, G.D. (2007), "International venturing by emerging economy firms: the effects of firm capabilities, home country networks, and corporate entrepreneurship", Journal of International Business Studies, Vol. 38, pp. 519-540. 
Zhang, F., Jiang, G. and Cantwell, J.A. (2015), "Subsidiary exploration and innovative performance of large multinational corporations", International Business Review, Vol. 24, pp. 224-234.

Zhang, Y. and Filippov, S. (2009), "Internationalization of Chinese firms in Europe”, Working Paper 041, Unu-Merit Maastricht.

Zhang, Y. and Roelfsema, H. (2014), "Unravelling the complex motivations behind China's outward FDI", Journal of the Asia Pacific Economy, Vol. 19 No. 1, pp. 89-100.

\section{Further reading}

Rugman, A.M., Verbeke, A. and Yuan, W. (2011), "Re-conceptualizing Bartlett and Ghoshal's classification of national subsidiary roles in the multinational enterprise", Journal of Management Studies, Vol. 48 No. 2, pp. 253-277.

\section{Corresponding author}

Philippe Gugler can be contacted at: phg88213@gmail.com

For instructions on how to order reprints of this article, please visit our website: www.emeraldgrouppublishing.com/licensing/reprints.htm Or contact us for further details: permissions@emeraldinsight.com 